\title{
Polymerase chain reaction genotyping of Epstein-Barr virus in scraping samples of the tongue lateral border in HIV-1 seropositive patients
}

\author{
TF Robaina, CP Valladares, DS Tavares, WC Napolitano, LE Silva', EP Dias, JPG Leite²+ \\ Programa de Pós-graduação em Patologia, 'Instituto de Matemática Universidade Federal Fluminense, Niterói, RJ, Brasil ²Laboratório de \\ Virologia Comparada, Instituto Oswaldo Cruz-Fiocruz, Av. Brasil 4365, 21045-900 Rio de Janeiro, RJ, Brasil
}

The Epstein-Barr virus (EBV) is the etiological agent of oral hairy leukoplakia (OHL), an oral lesion with important diagnostic and prognostic value in acquired immunodeficiency disease syndrome. The two EBV genotypes, $E B V-1$ and $E B V-2$, can be distinguished by divergent gene sequences encoding the EBNA-2, $3 A, 3 B$, and $3 C$ proteins. The purpose of this study was to identify the EBV genotype prevalent in 53 samples of scrapings from the lateral border of the tongue of HIV-1 seropositive patients, with and without OHL, and to correlate the genotypes with presence of clinical or subclinical OHL with the clinic data collected. EBV-1 and EBV-2 were identified through PCR and Nested-PCR based on sequence differences of the EBNA-2 gene. EBV-1 was identified in the 31 samples (15 without OHL, 7 with clinical OHL and 9 with subclinical OHL), EBV-2 in 12 samples (10 without OHL, 1 with clinical and 1 subclinical OHL), and a mixed infection in 10 samples ( 2 without OHL, 3 with clinical and 5 with subclinical OHL). The presence of EBV-1 was higher in women, but a significant statistical result relating one the EBV genotypes to the development of OHL was not found. We conclude that the oral epithelium in HIV-1 seropositive patients can be infected by EBV-1, EBV-2 or by a mixed viral population.

Key words: EBV-1 - EBV-2 - oral hairy leukoplakia - HIV-1 - EBNA-2 gene.

The Epstein-Barr virus (EBV) is a member of the Herpesviridae family and of the Gammaherpesvirinae subfamily. EBVs infect lymphocytes and epithelial cells, and were originally isolated from the African form of Burkitt's lymphoma (Epstein et al. 1964). EBV seroprevalence studies demonstrate that EBV antibodies are present in more than $90 \%$ of the world's population. EBV is the leading cause of infectious mononucleosis and is the etiological agent of oral hairy leukoplakia (OHL) (Cohen 2000, Young \& Rickinson 2004). OHL is clinically characterized as an asymptomatic white lesion, not removable through scraping, that develops at the peripheral border of the tongue, unilaterally or bilaterally. Eventually, it can appear in other sites of the mouth, such as the ventral surface of tongue, floor of the mouth, soft palate, and buccal mucosa (Greenspan et al. 1984, Greenspan \& Greenspan 1989). Its surface can be planar, corrugated or hairy, and it usually appears in patients that suffer from severe immunosuppression, especially those infected by the human immunodeficiency virus type-1 (HIV-1). OHL is associated with chronic, productive infection by the EBV (Greenspan et al. 1984, Greenspan \& Greenspan 1989, Triantos et al. 1998). Actually, OHL is the only epithelial manifestation known from replicative infection by EBV, and it occurs during the phase of higher expression of the genes and proteins coded by its genome (Webster-Cyriaque \& Raab-Traub 1998, Walling et al. 2004a, b). Some investigators recognize the occurrence of OHL under the subclinical form,

+ Corresponding author: jpgleite@ioc.fiocruz.br

Received: 11 November 2007

Accepted: 10 June 2008 which is identified by the cytophatics effects of EBV by histopathology or cytopathology, and DNA viral confirmation by polymerase chain reaction (PCR) (FragaFernandez et al. 1990, 1992, Dias et al. 2000, 2001).

In HIV-1 seropositive patients, OHL is considered a diagnostic lesion of the acquired immunodeficiency syndrome (AIDS). Its appearance in patients with no apparent immunosuppression signs may be the first clinical manifestation of HIV-1 infection (ECC 1993). OHL still is a prognostic marker for the development of AIDS. The emergence of OHL indicates an aggravation of the HIV-1 seropositive patient's health state, which is related to the increase of the number of HIV-1 RNA viral copies in the peripheral blood and reduction of CD4+ T lymphocytes, indicating disease progression, therapeutic failure, or viral resistance to the highly active anti-retroviral therapy (HAART) (Greenspan et al. 1987, 2004, Begg et al. 1996, Patton \& Hill 2000, Coogan et al. 2005).

Two EBV strains, type-1 (EBV-1) and type-2 (EBV-2), have been identified on the basis of divergent DNA sequences in the EBV-encoded nuclear antigens (EBNA) 2, 3A, 3B, and 3C (Adldinger et al. 1985, Rowe et al. 1989, Durmaz et al. 1998). The results of many serologic studies have demonstrated that the distribution of EBV-1 versus EBV-2 has characteristically different frequencies in distinct geographic locations (Gratama \& Ernberg 1995, Khanim et al. 1996). EBV-1 is prevalent in Western countries, whereas EBV-2 is prevalent in Africa, Oceania (New Guinea), and in HIV-1 seropositive patients, even in the Western countries. In addition, the biologic properties of these two types are also distinct. EBV-1 is more efficient to transform and immortalize infected B lymphocytes in vitro; whereas, EBV-2 is reported to be a weaker transformer (Gratama \& Ernberg 1995, Khanim et al. 1996, Cohen 2000). 
Little is known about the biological differences between the two types of EBV, particularly how they differ in their pathogenic potential in OHL pathogenesis, and the interaction between EBV proteins and the host proteins. EBV genotyping studies associated with OHL are rare worldwide (Triantos et al. 1998, Walling et al. 1999, Palefsky et al. 2002), and it is not yet established if there is prevalence of one of the genotypes in OHL cases from HIV-1 seropositive Brazilian patients.

The aim of this study was to verify the EBV genotypes present in samples obtained by scraping the lateral border of the tongue of HIV-1 seropositive patients, with and without clinical OHL, who previously tested as positive for EBV DNA, using PCR methodology based on genomic differences of the EBNA-2 gene.

\section{PATIENTS, MATERIALS AND METHODS}

Specimens - We analyzed 53 scraping samples from the lateral border of the tongue of HIV-1 seropositive patients, treated with HAART, with and without OHL, previously tested by PCR and Nested-PCR with positive results for EBV DNA using the protocol described by Durmaz et al. (1998). The diagnostic criterion for the subclinical form and for confirmation of clinical lesions of OHL was based on cytopathological abnormalities, through the identification of nuclear alterations characteristic of the cytopathic effect of EBV on keratinocytes: Cowdry A inclusion, ground glass, and nuclear beading (Fraga-Fernandez \& Vicandi-Plaza 1992, Migliorati et al. 1993, Dias et al. 2000, Milagres et al. 2007).

EBNA-2 gene amplification - DNA extraction was performed by the method described by Boom et al. (1990), including a modification by Araújo et al. (2001). The amplification was carried out by PCR using the E2P1 and E2P2 primer sets as described for $E B V-1$ and $E B V-2$ types, respectively, by Durmaz et al. (1998). For amplification of a $506 \mathrm{bp}$ fragment of the EBNA-2 gene, the protocol was followed with some modification. PCR was performed in $0.5 \mathrm{ml}$ microcentrifuge tubes in a final mixture of $50 \mu \mathrm{l}$, containing $0.125 \mu \mathrm{l}(5 \mathrm{U} / \mu \mathrm{l})$ of Taq Platinum DNA Polymerase (Invitrogen, Brazil), $1.5 \mathrm{mM}$ $\mathrm{MgCl}_{2}$ (Invitrogen ${ }^{\mathrm{TM}}$, Brazil), $0.2 \mathrm{mM}$ dNTP's (Invitrogen $^{\mathrm{TM}}$, Brazil), $5 \mu 1$ 10X buffer (Invitrogen ${ }^{\mathrm{TM}}$, Brazil), and $2 \mu \mathrm{l}(20 \mu \mathrm{M} / \mu \mathrm{L})$ of the above-mentioned primers. After denaturation of the DNA template at $94^{\circ} \mathrm{C} / 1 \mathrm{~min}$, the PCR cycling conditions (PTC 100/Peltier Effect Cycling, Programmable Thermo Controller) included 40 cycles of denaturation at $94^{\circ} \mathrm{C} / 30 \mathrm{~s}$, annealing at $58^{\circ} \mathrm{C} /$ $30 \mathrm{~s}$, and extension at $72^{\circ} \mathrm{C} / 1 \mathrm{~min}$, following 1 cycle of final extension at $72 \% 7 \mathrm{~min}$.

Nested-PCR - The typing method used the AP1 and AP2 pair of primers for $E B V-1$, and BP1 and BP2 for $E B V-2$, as described by Durmaz et al. (1998). Nested-PCR was performed with $2.5 \mu \mathrm{l}$ of the PCR product diluted $1: 100$, in a final mixture of $50 \mu \mathrm{l}$ containing the same reagents and concentrations described before. The nested -PCR conditions were modified as follow: after denaturation of the template DNA at $94^{\circ} \mathrm{C} / 1 \mathrm{~min}$, the Nested -PCR was performed for 25 cycles (PTC 100/Peltier
Effect Cycling, Programmable Thermo Controller) of denaturation at $94^{\circ} \mathrm{C} / 30 \mathrm{~s}$, annealing at $58^{\circ} \mathrm{C} / 20 \mathrm{~s}$, and extension at $72^{\circ} \mathrm{C} / 75 \mathrm{~s}$, following a final extension of 1 cycle at $72^{\circ} \mathrm{C} / 7 \mathrm{~min}$. The $E B V-1$ and $E B V-2$ amplicons corresponded to fragments of 497 and $150 \mathrm{bp}$, respectively (Figure). The PCR and nested-PCR amplicons were revealed on $2 \%$ agarose gel, followed by ethidium bromide staining $(0.5 \mathrm{mg} / \mathrm{ml})$, and visualization under UV light (Transluminator Labnet National Labnet Company). All known precautions were rigorously taken to avoid sample-sample contamination and PCR product carryover. Milli-Q water was used as negative control in all steps for the DNA extraction as a precaution to avoid false-positive results.

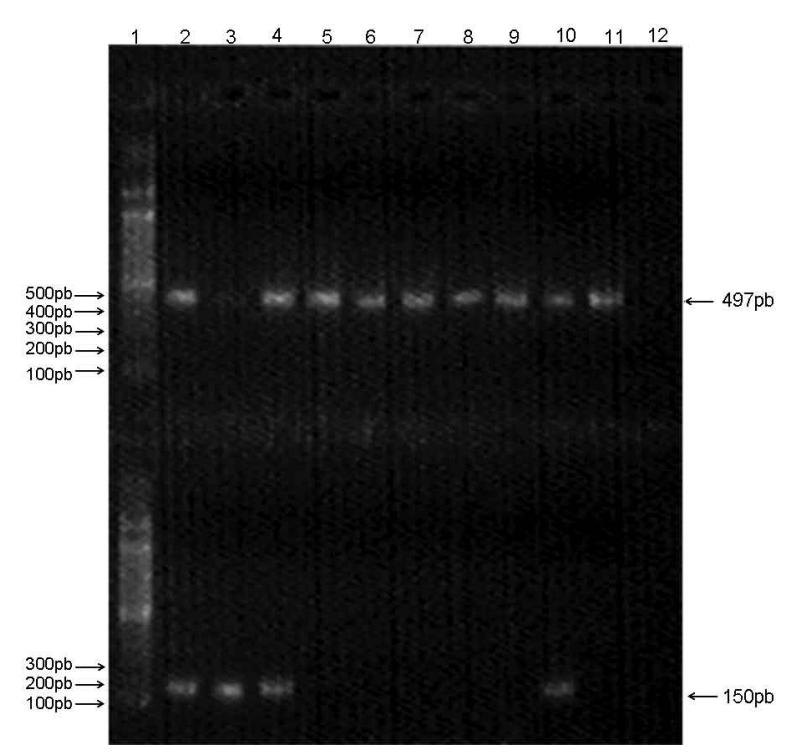

Agarose gel electrophoresis analysis of Nested-PCR products of Epstein-Barrvirus genotypes 1(EBV-1) and 2(EBV-2): Lanes-1:100 pb ladder molecular size marker; 5 - 9, 11: EBV-1 (497 pb product); 3: EBV-2 (150 pb product); 2, 4, 10: EBV-1 + EBV-2 co-infection; 12: negative control.

Statistical analysis - The statistical analysis was performed using SPSS software for Windows (version 11.0). The chi-square test for dependent samples was used for evaluation of the results obtained by PCR assays. The Fisher chi-square assays were used for comparison of the results from genotyping in relation to age, gender, form of HIV-1 infection of patients, and the presence or absence of clinical and subclinical OHL as described previously in the specimen description $(\mathrm{p}<0.05)$.

The Ethical Committee of Research of Hospital Universitário Antônio Pedro, Niterói, Rio de Janeiro, Brazil, approved this work on 04/20/2005 (CEP CMM/ HUAP 029/05).

\section{RESULTS}

Fifty-three scraping samples were collected from the right lateral border of the tongue of HIV-1 seropositive patients: $29(54.7 \%)$ and $24(45.3 \%)$ were from males and 
female patients, respectively. The patient age varied from 20 to 70 years (40.6 years, average). The total sample representation in relation to age is presented in Table I. Considering the form of HIV-1 infection in female patients, $22(91.7 \%)$ samples were from patients infected through heterosexual relationships, one (4.2\%) from use of intravenous drugs, and one (4.2\%) from blood transfusion. In relation to the form of HIV-1 infection in male patients, $26(89.7 \%)$ samples were from patients infected through homosexual relations, two $(6.9 \%)$ from heterosexual relations, and one (3.4\%) sample was from a patient who did not know how he was infected with HIV-1.

In $27(50.9 \%)$ of the 53 total samples analyzed, OHL was not detected by either clinical exams or by conventional cytopathology. Eleven (20.8\%) samples were from patients who had clinical OHL: six $(25 \%)$ female patients and five $(17.2 \%)$ male patients. Fifteen (28.3\%) samples were from patients who had subclinical OHL: seven (29.2\%) female patients, and eight (27.6\%) male patients.

From the 31 samples in which the presence of EBV-1 was detected alone, $19(61.3 \%)$ were from female patients, and $12(38.7 \%)$ from male patients. Considering the 12 samples in which EBV-2 was positive, three (25\%) were from female patients, and nine $(75 \%)$ from male patients. Taking into consideration the 10 samples with mixed infection, two $(20 \%)$ were from female patients and eight $(80 \%)$ from male patients. There was no significant statistical difference in the occurrence of EBV genotypes between male and female patients (Table II).

Considering the correlation between the genotypes and the detection of OHL from the 31 samples in which EBV-1 alone was detected, 15 (48.4\%) patients did not presented OHL, seven (22.6\%) had clinical OHL, and

\section{TABLE I}

Sample distribution in relation to the patient's age and gender $(\mathrm{n}=53)$

\begin{tabular}{lccc}
\hline & \multicolumn{2}{c}{ Gender } & \\
\cline { 2 - 3 } Age & Female & Male & Total of samples \\
\hline $20-30$ & $4(16.7 \%)$ & $6(20.7 \%)$ & $10(18.9 \%)$ \\
$31-40$ & $10(18.9 \%)$ & $6(20.7 \%)$ & $16(30.2 \%)$ \\
$41-50$ & $5(20.8 \%)$ & $12(41.4 \%)$ & $17(32.2 \%)$ \\
$51-60$ & $4(16.7 \%)$ & $4(13.8 \%)$ & $8(15.1 \%)$ \\
$61-70$ & $1(4.2 \%)$ & $1(3.4 \%)$ & $2(3.8 \%)$ \\
\hline Total & $24(45,3 \%)$ & $29(54,7 \%)$ & $53(100 \%)$ \\
\hline
\end{tabular}

TABLE II

Sample distribution in relation to the patient's gender and EBV genotypes $(\mathrm{n}=53)$

\begin{tabular}{lcrc}
\hline & \multicolumn{2}{c}{ Gender } & \\
\cline { 2 - 3 } Age & Female & \multicolumn{1}{c}{ Male } & Total of samples \\
\hline EBV-1 & $19(35.8 \%)$ & $12(22.7 \%)$ & $31(58.5 \%)$ \\
EBV-2 & $3(5.6 \%)$ & $9(16.9 \%)$ & $12(22.5 \%)$ \\
Mixed infection & $2(3.9 \%)$ & $8(15.0 \%)$ & $10(18.9 \%)$ \\
\hline Total & $24(45.3 \%)$ & $29(54.7 \%)$ & $53(100 \%)$ \\
\hline
\end{tabular}

nine $(29.0 \%)$ had subclinical OHL. From the samples where EBV-2 was detected, $10(83.3 \%)$ patients did not present OHL, one $(8.3 \%$ ) had clinical OHL, and one $(8.3 \%)$ had subclinical OHL. From the samples where both genotypes were detected, two (20.0\%) patients did not present OHL, three $(30.0 \%)$ had clinical OHL, and five $(50.0 \%)$ had subclinical OHL. There was no significant statistical difference between the occurrence of EBV genotypes in patients with or without clinical or subclinical OHL (Table III).

\section{TABLE III}

Sample distribution in relation to EBV genotypes and clinical/subclinical oral hairy leukoplakia $(n=53)$

\begin{tabular}{lcccc}
\hline & \multicolumn{3}{c}{ OHL } & Total of \\
\cline { 2 - 4 } & Clinical & Subclinical & None & samples \\
\hline EBV-1 & $7(13.2 \%)$ & $9(17 \%)$ & $15(28.3 \%)$ & $31(58.5 \%)$ \\
EBV-2 & $1(1.8 \%)$ & $1(1.8 \%)$ & $10(18.8 \%)$ & $12(22.5 \%)$ \\
Mixed infection & $3(5.6 \%)$ & $5(9.4 \%)$ & $2(3.9 \%)$ & $10(18.9 \%)$ \\
\hline Total & $10(20.6 \%)$ & $15(28.3)$ & $27(51 \%)$ & $53(100 \%)$ \\
\hline
\end{tabular}

\section{DISCUSSION}

The identification of EBV strains has been used in many studies to investigate issues concerning the biology of infection and the nature of viral persistence (SitkiGreen et al. 2002). The different EBV genotypes have been investigated as the possible source of differences in the prognosis of various diseases, such as nasopharyngeal carcinoma and gastric adenocarcinoma (Higa et al. 2001, Busson et al. 2004, Williams \& Crawford, 2005). OHL is a lesion associated with the EBV replicative cycle and its pathogenesis is not yet totally resolved. In addition, it is not known if any EBV genotype is associated with or influences the development of the clinical or subclinical appearance of OHL.

As previously described in this study, the diagnostic criterion for OHL was based in the cytopathological diagnosis through the identification of nuclear alterations that represent the cytopathic effect of EBV on keratinocytes: Cowdry A inclusion, ground glass, and nuclear beading. Although these alterations are observed in both histopathological and cytopathological exams, the latter has been considered the best method for the diagnosis of clinical and subclinical OHL (Fraga-Fernandez \& Vicandi-Plaza 1992, Migliorati et al. 1993, Dias et al. 2000, Milagres et al. 2007).

The prevalence of clinical OHL (20.8\%) was similar to what was described by previous studies (Greenspan et al. 2004). However, studies that only consider clinical criteria to establish the diagnosis of OHL have lower prevalence results (Walling et al. 1994, 2004b, WebsterCiriaque \& Raab-Traub, 1998). In this study, subclinical OHL was observed in $28.3 \%(15 / 53)$ of the patients because cytopathologic criteria were used to confirm the presence of clinical OHL and to detect subclinical OHL. Because both clinical and subclinal OHL were considered, the prevalence rate established in this study was 
higher than that in some previous studies (49.3\%) (Dios et al. 2000, Schmidt-Westhausen et al. 2000, Greenspan et al. 2004). The cytopathologic criterion used to confirm the presence of clinic OHL is important for two reasons: (i) it is used to differentiate clinical OHL from other white oral lesions; (ii) it is used to detect subclinical OHL, because when its presence is not considered, the real prevalence of OHL in the HIV-1 seropositive individuals after introduction of HAART may be neglected. Interestingly, the prevalence of subclinical OHL was higher than clinical OHL. The low prevalence of clinical OHL is expected in users of HAART (Tappuni et al. 2001, Greenspan et al. 2004). However, it is not clear whether subclinical OHL is a phase before or after the emergence of clinical OHL, or whether it has some prognostic value (Dias et al. 2000, 2001). More studies need to be done in order to answer this question.

According to Correa et al. (2004), several studies have shown discrepancies between frequencies of EBV genotypes based on the analysis of certain genes such as EBNA-2, 3A, 3B, and 3C. When applying PCR on viral DNA from cell culture isolation of clinical samples, in most of the cases, only one genotype, usually EBV-1, is detected. In contrast, when applying PCR directly on clinical samples, co-infection with both EBV genotypes was observed. The discrepancies may be attributed to biological differences between genotypes, in which the EBV-1 is more efficient than EBV-2 in the immortalization of growing B-cells in vitro. In attempt to avoid this tendency, the present study used PCR methodology directly in the same sample collected for cytopathology, through storage in a TBS filled tube of the active point of the endocervical brush used for scraping of the tongue.

The highest prevalence of EBV-1 occurs in the Western countries (Khanim et al. 1996, Higa et al. 2001, Chabay et al. 2004). In this study, EBV-1 was the most common genotype detected in $80.4 \%(41 / 53)$ of the samples. In contrast to some studies, which proposed that in HIV-1 infected individuals there is high prevalence of the EBV type 2 infection or superinfection with both type 1 and 2 (Sculley et al. 1990, van Baarle et al. 2000), our study identified EBV-2 in $43.1 \%$ of cases $(22 / 53)$. However, mixed infections were detected in $18.9 \%$ $(10 / 53)$ of samples analyzed, similar to the study by Triantos et al. (1998) (Table II).

When we compared the groups of men and women, the occurrence of EBV-2 was proportionally higher in men $(17 / 22)$ than in women $(5 / 22),\left(p<0.001 ; \chi^{2}=13\right)$. This may be related to the fact that $89.7 \%$ of the men were infected through homosexual relations. In accordance with Yao et al. (1998) and van Baarle et al. (2000), there is a high prevalence of EBV-2 in HIV-1 seropositive male homosexual patients. These authors concluded that EBV-2 infection is more prevalent among homosexual men and it is caused by sexual transmission: (i) a significant association was found between EBV-2 infection and a greater number of partners; (ii) HIV-1 seropositive homosexual men have higher EBV-2 prevalence than do HIV-1 seronegative homosexual men. A more likely explanation may be that HIV-positive persons tend to have sex with HIV-seropositive persons, leading to more EBV-2 exposure for those who are HIV-seropositive (van Baarle et al. 2000).

Comparing the genotyping result from the samples provided by patients with clinical or subclinical OHL and without OHL, we found no significant statistical difference between the prevalence of genotypes. A detailed statistical analysis could not be done due to the reduced number of samples. However, we could observe that in the samples where both EBV genotypes were found, subclinical OHL was present in $50 \%$ of the patients, and clinical OHL in 30\%. These data might suggest that there is a synergism between the genotypes and the occurrence of OHL, because $80 \%$ of the patients from this group presented some form of OHL (Table III). Some studies described that the viral variants, intrastrain recombination, and deletion are more important in the pathogenesis of the diverse diseases associated with EBV than the genotypes per se (Walling et al. 1994, Oshima et al. 1999, Sitki-Green et al. 2002). However, the role of the EBV genotypes in the pathogenesis of OHL deserves further investigation.

In relation to the age and gender of patients, there is a balance between male and female patients and the patients in different ages. This data represents the actual image of HIV-1/AIDS epidemic in Brazil, and the increase of its incidence in women and across almost all age groups (MS 2005).

It would be interesting to develop a study comparing samples of the lateral border scrapings with the blood samples of these patients in order to evaluate the genotypes found. Furthermore, it is necessary to investigate the transitoriness of a particular genotype during the patient's life phases, because there may be a possibility that in some moments there is a stronger incidence of EBV-1, and in others, of EBV-2. In addition, the constant re-infections may influence the identified genotype and benefit intra-recombining strains and mutations that may or may not influence the emergence of OHL.

Like other studies reported in the literature, it was not possible to be certain about the association between the genotypes and the development of OHL. We suggest that prospective studies of clinical follow up through cytopathology, together with genotyping and genomic sequencing from collected samples, should be performed to fully address the links between EBV and the development of OHL.

\section{REFERENCES}

Adldinger HK, Delius NK, Freese J, Bornkamm GW 1985. A putative transforming gene of Jijoye virus differs from that of EpsteinBarr virus prototypes. Virology 141: 221-228.

Araújo IT, Ferreira MSR, Fialho AM, Assis RM, Cruz CM, Rocha M, Leite JPG 2001. Rotavirus genotypes P[4]G9, P[6]G9, and P[8] G9 in hospitalized children with acute gastroenteritis in Rio de Janeiro, Brazil. J Clin Microbiol 39: 1999-2001.

Begg MD, Panageas KS, Mitchell-Lewis D, Bucklan RS, Phelan JA, Lamster IB 1996. Oral lesions as markers of severe immunosuppression in HIV-infected homosexual men and injection drug users. Oral Surg Oral Med Oral Pathol Oral Radiol Endod 82: 276-283. 
Boom R, Sol CJ, Salimans MM, Jansen CL, Wertheim-van Dillen PM, van der Noordaa J 1990. Rapid and simple method for purifications of nucleic acids. J Clin Microbiol 28: 495-503.

Busson P, Keryer C, Ooka T, Corbex M 2004. EBV-associated nasopharyngeal carcinomas: from epidemiology to virus-targeting strategies. Trends Microbiol 12: 356-360.

Chabay P, De Matteo E, Merediz A, Preciado MV 2004. High frequency of Epstein Barr virus latent membrane protein-1 $30 \mathrm{bp}$ deletion in a series of pediatric malignancies in Argentina. Arch Virol 149: 1515-1526.

Cohen JI 2000. Epstein-Barr virus infection. $N$ Engl J Med 343: 481-492.

Coogan MM, Greenspan J, Challacombe SJ 2005. Oral lesions in infection with human immunodeficiency virus. Bull World Health Organ 83: 700-706.

Correa RM, Fellner MD, Alonio LV, Durand K, Teyssié AR, Picconi MA. Epstein-Barr virus in healthy carriers: distribution of genotypes and $30 \mathrm{pb}$ deletion in latent membrana-1 oncogene. J Med Virol 73: 583-588.

Dias EP, Rocha ML, Silva Júnior A, Spyrides KS, Ferreira SM, Polignano GA, Feijó EC, Da Fonseca EC 2000. Oral hairy leukoplakia: histopathologic and cytopathologic features of a subclinical phase. Am J Clin Pathol 11: 394-400.

Dias EP, Spyrides KS, Silva Júnior A, Rocha ML, Da Fonseca EC 2001. Oral hairy leukoplakia: histopathologic features of subclinical stage. Pesq Odontol Bras 15: 104-111.

Dios PD, Ocampo A, Miralles C, Limeres J, Tomás I 2000. Changing prevalence of human immunodeficiency virus-associated oral lesions. Oral Surg Oral Med Oral Pathol Oral Radiol Endod 90: 403-404.

Durmaz R, Aydin A, Köroglu M, Aker H, Ozercan IH, Atik E, Arici S 1998. Detection and genotyping of Epstein-Barr virus by polymerase chain reaction in tissue obtained from cases with Hodgkin's disease in Turkey. Acta Virol 42: 375-381.

ECC - EC-Clearinghouse on Oral Problems Related to HIV Infection and WHO Collaborating Center on Oral Manifestations of the Immunodeficiency Virus 1993. Classification and diagnostic criteria for oral lesions in HIV infection. J Oral Pathol Med 22: 289-291.

Epstein M, Achong B, Barr, Y 1964. Virus particles in cultured lymphoblasts from Burkitt's lymphoma. Lancet 15: 702-703.

Fraga-Fernandez J, Benito C, Lizaldez EB 1990. Oral hairy leukoplakia: a histopathologic study of 32 cases. Am J Dermatopathol 12: $571-578$.

Fraga-Fernandez J, Vicandi-Plaza B 1992. Diagnosis of hairy leukoplakia by exfoliative cytologic methods. Am J Clin Pathol 97: 262-266.

Gratama JW, Ernberg I 1995. Molecular epidemiology of EpsteinBarr virus infection. Adv Cancer Res 67: 197-253.

Greenspan D, Gange SJ, Phelan JA, Navazesh M, Alves ME, MacPhail LA, Mulligan R, Greenspan JS 2004. Incidence of oral lesions in HIV-1-infected women: reduction with HAART. J Dent Res 83: 145-150.

Greenspan D, Greenspan JS, Conant M, Petersen V, Silverman S Jr, de Souza Y 1984. Oral hairy leukoplakia in male homosexuals: evidence of association with both papillomavirus and herpes group virus. Lancet 2: 831-834.

Greenspan D, Greenspan JS, Hearst NG, Pan LZ, Conant MA, Abrams DI, Hollander H, Levy JA 1987. Relation of oral hairy leukoplakia to infection with the human immunodeficiency virus and the risk of developing AIDS. J Infect Dis 155: 475-481.
Greenspan JS, Greenspan D 1989. Oral hairy leukoplakia: diagnosis and management. Oral Surg Oral Med Oral Pathol Oral Radiol Endod 67: 396-403.

Higa M, Kinjo T, Miyagi J, Sakumoto N, Iwamasa T, Kishaba M, Sunakawa H 2001. Differences in EBNA2 and LMP carboxy terminal region sequences of Epstein-Barr virus type A between the tumors in a multiple cancer patient. Pathol Res Pract 197: 401-409.

Khanim F, Yao QY, Niedobitek G, Sihota S, Rickinson AB, Young LS 1996. Analysis of Epstein-Barr virus gene polymorphisms in normal donors and in virus-associated tumors from different geographic locations. Blood 88: 3491-3501.

Migliorati CA, Jones AC, Baughman PA 1993. Use of exfoliative cytology in the diagnosis of oral hairy leukoplakia. Oral Surg Oral Med Oral Pathol 76: 704-710.

Milagres A, Dias EP, Tavares DS, Cavalcante RM, Dantas VA, Oliveira SP, Leite JPG 2007. Prevalence of oral hairy leukoplakia and epithelial infection by Epstein-Barr virus in pregnant women and diabetes mellitus patients cytopathologic and molecular. Mem Inst Oswaldo Cruz 102: 159-164.

MS - Ministério da Saúde 2005. Boletim Epidemiológico - AIDS e DST 2005. [Cited 2005 Dez 18]. Available from: http://www.aids.gov.br.

Oshima M, Azuma H, Okuno A 1999. High prevalence of EpsteinBarr virus type A strain with the 30 b.p. deletion of the latent membrane protein-1 gene in a Japanese population. Pediatr Int 41: 490-495.

Palefsky JM, Berline J, Greenspan D, Greenspan JS 2002. Evidence for trafficking of Epstein-Barr virus strains between hairy leukoplakia and peripheral blood lymphocytes. J Gen Virol 83: 317-321.

Patton L, Hill C 2000. Sensitivity, specificity, and positive predictive value of oral opportunistic infections in adults with HIV/AIDS as markers of immunessuppression and viral burden. Oral Surg Oral Med Oral Pathol Oral Radiol Endod 90: 182-188.

Rowe M, Young LS, Cadwallader L, Petti L, Kieff E, Rickinson AB 1989. Distinction between Epstein-Barr virus type A (EBNA 2A) and type B (EBNA 2B) isolates extends to the EBNA 3 family of nuclear. $J$ Virol 63: 1031-1039.

Schmidt-Westhausen AM, Priepke F, Bergmann FJ, Reichart PA 2000. Decline in the rate of oral opportunistic infections following introductio of highly active antiretroviral therapy. J Oral Pathol Med 29: 336-341.

Sculley TB, Apolloni A, Hurren L, Moss DJ, Cooper DA 1990. Coinfection with A- and B-type Epstein-Barr virus in human immunodeficiency virus positive subjects. J Infect Dis 162: 643-648.

Sitki-Green D, Edwards RH, Webster-Cyriaque J, Raab-Traub N 2002. Identification of Epstein-Barr virus strain variants in hairy leukoplakia and peripheral blood by use of a heteroduplex tracking assay. $J$ Virol 76: 9645-9656.

Tappuni AR, Fleming JP 2001. The effect of antiretroviral therapy on the prevalence of oral manifestations in HIV-infected patients: a UK study. Oral Surg Oral Med Oral Pathol Oral Radiol Endod 92: 623-628.

Triantos D, Leao JC, Porter SR, Scully CM, Teo CG 1998. Tissue distribution of Epstein-Barr virus genotypes in hosts coinfected by HIV. AIDS 12: 2141-2146.

van Baarle D, Hovemkamp E, Dukers NHTM, Renwick N, Kersten MJ, Goudsmit J, Coutinho R, Miedema F, Oers MHJV 2000. High Prevalence of Epstein-Barr virus type-2 among homosexual men is caused by sexual transmission. J Infect Dis 181: 2045-2049.

Walling DM, Flaitz CM, Hosein FG, Montes-Walters M, Nichols CM 2004a. Effect of Epstein-Barr virus replication on a Langerhans cells in pathogenesis of oral hairy leukoplakia. J Infect Dis 189: 1656-1663. 
Walling DM, Ling PD, Gordadze AV, Montes-Walters M, Flaitz CM, Nichols CM 2004b. Expression of Epstein-Barr latent genes in oral epithelium: determinants of the pathogenesis of oral hairy leukoplakia. J Infect Dis 190: 396-399.

Walling DM, Raab-Traub N 1994. Epstein-Barr virus intrastrain recombination in oral hairy leukoplakia. J Virol 68: 7909-7917.

Walling DM, Shebid N, Weaver SC, Nichols CM, Flaitz CM, WebsterCyriaque J 1999. The molecular epidemiology and evolution of Epstein-Barr virus: sequence variation and genetic recombination in the latent membrane protein-1 gene. J Infect Dis 179: 763-774.

Webster-Cyriaque J, Raab-Traub N 1998. Transcription of Epstein-
Barr virus latent cycle genes in oral hairy leukoplakia. Virology 248: 53-65.

Williams H, Crawford D 2006. Epstein- Barr virus: impact of scientific advance on clinical practice. Blood 107: 862-869.

Yao QY, Croom-Carter DS, Tierney RJ, Habeshaw G, Wilde JT, Hill FG, Conlon C, Rickinson AB 1998. Epidemiology of infection with Epstein-Barr virus types 1 and 2: lesions from the study of a T-cell-immunocompromised hemophilic cohort. J Virol 72: 4352-4363.

Young LS, Rickinson A 2004. Epstein-Barr virus: 40 years on. Nat Rev Cancer 4: 757-768. 